\title{
Pengaruh Green Marketing Mix terhadap Brand Image Produk Tupperware
}

\author{
Genoveva Genoveva \\ Fakultas Bisnis President University \\ Jl. Ki Hajar Dewantara, Kota Jababeka, Cikarang Baru, Bekasi, Indonesia \\ genoveva@president.ac.id \\ Wulan Berliana \\ Fakultas Bisnis President University \\ Jl. Ki Hajar Dewantara, Kota Jababeka, Cikarang Baru, Bekasi, Indonesia \\ wulanberlianal@gmail.com
}

Diterima: 27-08-2020

Disetujui: 28-12-2020

Dipublikasi: 30-01-2021

\begin{abstract}
ABSTRAK
Pertumbuhan industri yang semakin pesat membawa dampak terhadap permasalahan sosial dan lingkungan hidup, salah satunya adalah global warming. Masyarakat sebagai kelompok konsumen yang peduli terhadap lingkungannya dan bertanggungjawab terhadap kerusakan lingkungannya disebut sebagai Green Consumer. Dengan adanya Green Consumer, perusahaan diharapkan mampu menciptakan proses pemasaran yang lebih memperhatikan lingkungan dan memberikan dampak positif terhadap brand image. Penelitian ini bertujuan untuk mengetahui pengaruh green marketing mix secara parsial dan simultan terhadap brand image pada produk Tupperware. Variabel independen dalam penelitian ini terdiri dari green product $\left(\mathrm{X}_{1}\right)$, green price $\left(\mathrm{X}_{2}\right)$, green place $\left(\mathrm{X}_{3}\right)$, dan green promotion $\left(\mathrm{X}_{4}\right)$ dengan variabel dependennya yaitu brand image $(\mathrm{Y})$. Penelitian ini merupakan penelitian kuantitatif dengan analisis data deskriptif, menggunakan regresi linier berganda untuk mengetahui signifikansi dan probabilitas pengaruh variabel independen terhadap variabel dependen. Populasi dalam penelitian ini adalah konsumen yang menggunakan produk Tupperware di Jawa. Sampel dalam penelitian ini berjumlah 200 responden perempuan dengan menggunakan purposive sampling melalui kuesioner online. Hasil penelitian menunjukan bahwa variabel green product, green price dan green place secara signifikan berpengaruh terhadap brand image produk Tupperware. Sedangkan variabel green promotion tidak memiliki pengaruh terhadap brand image produk Tupperware. Green Price memberikan kontribusi terbesar terhadap Brand Image, maka manajemen perusahaan dapat memberikan perhatian khusus terhadap faktor harga yang sangat mempengaruhi Brand Image, sehingga penetuan harga harus memperhitungkan faktor lingkungan jangka panjang.
\end{abstract}

\section{Kata Kunci:}

Green product, green price, green place, green promotion, brand image

\begin{abstract}
The rapid growth of the industrial has an impact on social and environmental problems, one of which is global warming. Society as a group of consumers who care about their environment and are responsible for environmental damage is called the Green Consumer. With the Green Consumer, the company is expected to be able to create marketing processes that pay more attention to the environment and have a positive impact on brand image. This study aims to determine the effect of green marketing mix partially and simultaneously on brand image on Tupperware products. The independent variables in this study consisted of green product $\left(X_{1}\right)$, green price $\left(X_{2}\right)$, green place $\left(X_{3}\right)$, and green promotion $\left(X_{4}\right)$ with the dependent variable brand image $(Y)$. This research is a quantitative study with descriptive data analysis, using multiple linear regression to determine the significance and probability of the effect of independent variables on the dependent variable. The population in this study are consumers who use Tupperware products in Java. The sample in this study amounted to 200 respondents using purposive sampling through an online questionnaire. The results showed that the green product, green price and green place variables significantly affected the Tupperware product brand image. While the green promotion variable does not have an influence on the Tupperware product brand image. Green
\end{abstract}


Price gives the biggest contribution to Brand Image, therefore, the company should be pay special attention to price factors that greatly affect Brand Image, especially for long-term environmental factors.

Keywords:

Green product, green price, green place, green promotion, brand image 


\section{PENDAHULUAN}

Pada 2017 jumlah industri plastik di Indonesia mengalami kenaikan 5\% dari tahun sebelumnya yaitu mencapai 925 perusahaan dengan total produksi sebesar 4,68 juta ton dan perkiraan pertumbuhan pada tahun 2018 adalah 5,8\%. Kenaikan dalam tingkat produksi industri plastik menimbulkan potensi kerusakan lingkungan hidup. Menurut Olivar (2018) sampah plastik menyimpan kandungan karbon dan hidrogen yang akan berkumpul dengan zat klorida yang ditemukan pada sisa makanan yang campurannya akan melepaskan zat berbahaya bagi manusia.

Sejak 2010 Indonesia tercatat sebagai negara penyumbang sampah plastik nomor 2 di dunia (Choirun, 2018; Genoveva, 2016). Pada tahun 2018 sampah plastik telah mencapai 3,22 juta ton (Choirun, 2018). Di balik kerusakan lingkungan hidup, terdapat sekelompok masyarakat yang memiliki kesadaran terhadap lingkungan hidup. Konsumen yang memiliki kepedulian pada lingkungan, disebut sebagai Green Consumer. Adanya Green Consumer menumbuhkan dan memaksa industri untuk lebih peduli akan lingkungan dan mampu menciptakan produk yang ramah lingkungan (Mothersbaugh \& Hawkins, 2015; Sharma \& Trivedi, 2016).

Green Marketing merupakan strategi pemasaran yang efektif dan dapat meningkatkan brand image yang baik bagi perusahaan (Hasan \& Ali, 2015). Green marketing juga berpengaruh terhadap green brand image (Nguyen \& Nguyen, 2018). Brand image adalah persepsi dan kepercayaan konsumen yng tertanam di dalam memorinya (Keller, 2010), sehingga keputusan pembelian konsumen sangat dipengaruhi oleh image mereka terhadap produk atau jasa tersebut (Schifftman \& Kanuk, 2010). Brand image yang baik akan membuat konsumen tidak mudah pindah ke produk lain (Keller, 2010). Dengan adanya brand image yang baik, perusahaan akan mendorong konsumen melakukan pembelian produk (Agustin, Kumadji, \& Yulianto, 2015; Silvia, 2014; Simão \& Lisboa, 2017).

Tupperware merupakan salah satu perusahaan yang masuk ke Indonesia sejak 1991 dengan mengkampayekan green marketing dalam program reduce dan reuse (Supriadi, 2015). Reduce, merupakan pengurangan penggunaan tempat makan /minum sekali pakai dan membiasakan untuk membawa bekal dari rumah untuk keperluan makan / minum. Reuse, merupa-kan penggunaan tempat makan / minum yang tidak memiliki kandungan bahan yang membahayakan dan memiliki pemakaian berulang kali serta pemberian garansi seumur hidup untuk semua produk Tupperware (Supriadi, 2015). Strategi green marketing dari Tupperware diharapkan memberikan persepsi yang positif terhadap brand image perusahaan. 
Walaupun telah melakukan strategi green marketing mix di dalam pemasaran-nya, Tupperware mengalami penurunan brand index dalam 3 tahun terakhir yaitu tahun 2015 sebesar 50,5\%, di tahun 2016 mengalami penurunan menjadi 44,6\% dan di tahun 2017 menjadi 43,3\% (Top Brand Index, 2017). Di tahun 2018 Tupperware mencatatkan penurunan penjualan 14\% (Direct Selling News, 2019). Penurunan brand index dan penjualan, membuat Tupperware melakukan re-brand di tahun 2018 untuk memperkuat brand image dengan tagline baru yaitu "confidance becomes you" (Re-brand, 2018). Dengan tagline baru ini, diharapkan pemberdayaan perempuan sebagai tim yang tergabung dalam jaringan penjualan akan semakin memperkuat brand image Tupperware. Berdasarkan permasalahan ini, tujuan penelitian ini adalah mengetahui "pengaruh green marketing mix terhadap brand image Produk Tupperware”. Perbedaan penelitian ini dengan penelitian terdahulu adalah meneliti pengaruh re-brand yang dlakukan tahun 2018 dengan pemberdayaan perempuan dalam memperkuat jaringan pemasaran, sehingga responden dalam penelitian ini keseluruhannya adalah perempuan dan membeli produk Tupperware pada periode 2019 dengan lokasi penelitian di pulau Jawa yang merupakan wilayah penjualan tertinggi.

\section{TINJAUAN TEORI}

Marketing mix adalah strategi yang dilakukan perusahaan terhadap konsumen dengan pendekatan yang mudah dan fleksibel (Kotler \& Keller, 2017). Di dalam konteks green marketing mix, strategi yang dilakukan perusahaan adalah dengan memperhatikan lingkungan untuk menjaga keberlanjutannya (Karunarathna, Bandara, Silva, \& De Mel, 2020). Adapun komponen green marketing mix yang akan dipakai dalam penelitian ini terdiri dari green product, price, place dan promotion.

Green product adalah hasil produksi yang dapat mengurangi dampak lingkungan dengan melakukan efisiensi terhadap sumberdaya, dapat di daur ulang dan bersifat alami (Mahmoud, 2018). Menurut Kumar \& Ghodeswar (2015) green product adalah produk yang memiliki kandungan yang sehat dan proses produksinya ramah lingkungan. Simão \& Lisboa (2017) dalam konteks produk Toyota menyimpulkan bahwa, produk yang ramah lingkungan dapat mempengaruhi brand image dari produk tersebut sehingga meningkatkan minat beli konsumen. Hal senada dikemukan oleh (Rahmat \& Silvianita (2016) yang meneliti produk Bodyshop. Dalam mengembangkan suatu produk yang memakai konsep green akan meningkatkan brand image dari produk tersebut (Nguyen \& Nguyen, 2018). Berdasarkan ketiga, hasil penelitian tersebut maka hipotesis pertama dalam penelitian ini adalah: 
$\mathrm{H}_{1}$ : Green Product berpengaruh positif dan signifikan terhadap Brand Image produk Tupperware.

Green price adalah merupakan harga yang ditentukan oleh perusahaan dengan mempertimbangkan faktor lingkungan (Rajeshkumar, 2012). Pada umumnya konsumen akan siap untuk membayar lebih jika produk yang dibeli memiliki nilai tambah sebagai produk yang berkualitas dan ramah lingkungan (Genoveva \& Levina, 2019). Menurut Masterson \& Pickton (2014) ada beberapa elemen yang menjadi bahan pertimbangan perusahaan dalam menentukan harga suatu produk yaitu ekspektasi harga konsumen, harga produk dari pesaing, dan modal atau biaya yang dikeluarkan.

Dwipamurti, Mawardi, \& Nuralam (2018) dalam konteks Starbuck sebagai objek penelitian menyimpulkan bahwa green marketing mempengaruhi brand image, dimana salah satu indikator yang digunakan adalah green price. Senada dengan penelitian Romadon, Kumadji, \& Abdillah (2014) tentang "Pengaruh Green Marketing Terhadap Brand Image' dengan objek bahan bakar ramah lingkungan menyimpulkan bahwa green price memiliki pengaruh positif dan sifgnifikan terhdap brand image. Demikian juga dengan Ayu \& Wardhana (2016) menyimpulkan bahwa green price berpengaruh terhadap brand image pada produk Bodyshop. Berdasarkan hasil penelitian terdahulu maka hipotesis kedua dalam penelitian ini dapat dirumuskan sebagai berikut:

$\mathrm{H}_{2}$ : Green Price berpengaruh positif dan signifikan terhadap Brand Image produk Tupperware.

Green place adalah stategi menyalurkan produk dengan mengurangi dampak dari transportasi dan distribusi (Mahmoud, Ibrahim, Ali, \& Bleady, 2017). Definisi ini menunjukkan bahwa green place adalah saluran distribusi yang ramah lingkungan, dalam hal ini dengan memilih sistem transportasi yang tepat (Ayu \& Wardhana, 2016), sehingga polusi terhadap lingkungan rendah (FuiYeng \& Yazdanifard, 2015). Sementara Solaiman, Osman, Suberi, \& Halim (2015) memberikan contoh bahwa memilih produk lokal lebih berdampak rendah terhadap lingkungan daripada produk import.

Beberapa hasil penelitian terdahulu menunjukkan bahwa green place berpengaruh positif dan signifikan terhadap brand image, antara lain dari Putripeni, Suharyono, \& Kusumawati (2014) yang meneliti produk Bodyshop. Demikian juga dengan Genoveva \& Samukti (2020) dalam penelitian tentang Ades dengan botol ramah lingkungan dan Romadon et al. (2014) pada bahan bakar ramah lingkungan. Berdasarkan kesimpulan diatas maka hipotesis ketiga dalam penelitian ini adalah: 
$\mathrm{H}_{3}$ : Green Place berpengaruh positif dan signifikan terhadap Brand Image produk Tupperware.

Green Promotion dikenal sebagai aktivitas periklanan yang mendorong konsumen membeli dan menggunakan produk ramah lingkungan (Mahmoud et al., 2017). Green promotion juga menyediakan informasi, bukti dan alasan yang terkait dengan green product, sehingga membuat konsumen tertarik dengan produk tersebut (FuiYeng \& Yazdanifard, 2015)Cara-cara seperti ini merupakan upaya dalam meningkatkan perhatian konsumen terhadap lingkungan, ekologi dan kesehatan (Kalsi \& Singh, 2015).

Green promotion memiliki pengaruh yang positif dan signifikan terhdap brand image suatu produk / perusahaan, hasil penelitian ini dikemukakan oleh Putripeni et al. (2014), Sari \& Setiawan (2017), dan Dwipamurti et al. (2018) di lokasi dan tahun yang berbeda, namun menunjukkan kesimpulan yang sama. Sehingga hipotesis keempat dalam penelitian ini adalah:

$\mathrm{H}_{4}$ : Green Promotion berpengaruh positif dan signifikan terhadap Brand Image produk Tupperware.

Brand image adalah persepsi konsumen ketika pertama kali mendengar sebuah slogan dan melekat pada ingatannya (Kotler \& Keller, 2017). Aaker (2014) mengemukakan bahwa dalam persaingan, agar konsumen konsumen tetap memiliki ingatan terhadap produk, perusahaan biasanya menciptakan tampilan yang khusus, baik dalam bentuk logo, maupun kemasan. Sehingga brand image dapat dikatakan sebagai hal yang snagat penting dalam memenangkan persaingan (Simão \& Lisboa, 2017). Jika produk tersebut memiliki image yang baik maka akan dpilih oleh konsumen, namun apabila produk tersebut bermasalah akan dijauhi oleh konsumen (Genoveva \& Samukti, 2020).

Penelitian Rahmat \& Silvianita (2016) dan Ayu \& Wardhana (2016) yang sama-sama meneliti produk Bodyshop menunjukkan bahwa green marketing mix berpengaruh terhadap brand image. Kesimpulan yang sama dikemukakan oleh Genoveva \& Samukti (2020) dalam konteks air mineral Ades dengan kemasan ramah lingkungannya. Berdasarkan hasil penelitian ini maka hipotesis kelima dalam penelitian ini adalah:

$\mathrm{H}_{5}$ : Secara simultan Green Product, Price, Place dan Promotion berpengaruh positif dan signifikan terhadap Brand Image produk Tupperware. 
Berdasarkan 5 hipotesis di atas maka model penelitian dapat digambarkan sebagai berikut :

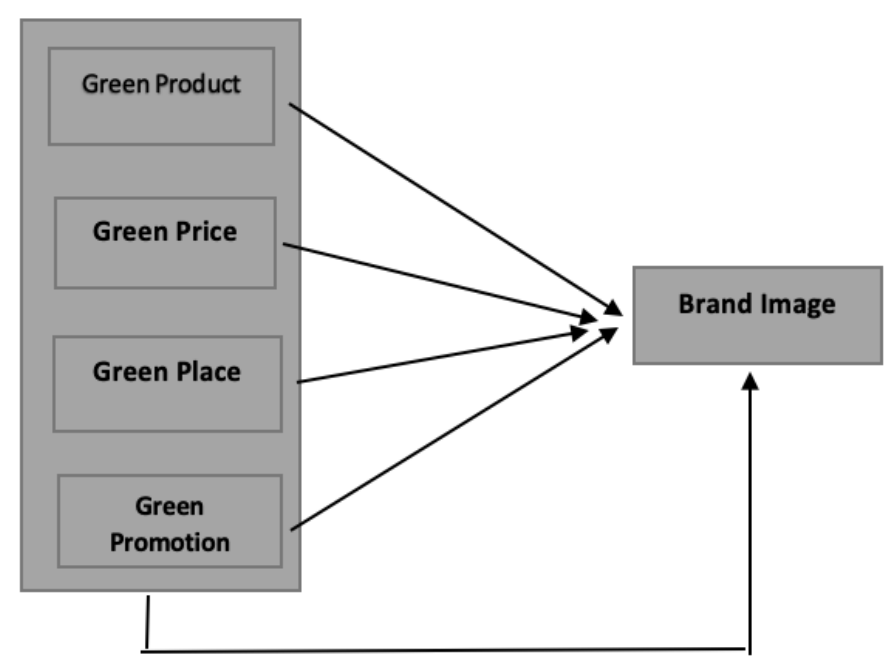

Gambar 1. Model Penelitian

Sumber: Rahmat \& Silvianita (2016)

\section{METODE RISET}

Penelitian ini menggunakan penelitian kuantitatif, yaitu penelitian tentang fenomena yang terjadi, dimana landasan teori digunakan sebagai pemandu dalam penelitian Sugiyono (2017). Alat pengumpulan data menggunakan kuesioner dan di desain sebanyak 40 pertanyaan.

Tahap awal kuesioner, dilakukan uji validitas dan reliabilitas dengan menyebarkan kuesioner kepada 30 responden (Hair, Anderson, Tatham, \& Black, 2010). Setelah semua pertanyaan valid dan reliabel, maka kuesioner disebarkan kepada konsumen yang pernah membeli produk Tupperware di pulau Jawa pada bulan Desember 2019. Pemilihan lokasi pulau Jawa karena pangsa pasar terbesar di Indonesia, yaitu 50\% (Antika, 2017). Untuk memastikan konsumen mengenal produk Tupperware, kuesioner dirancang dengan pertanyaan screening, yaitu “Apakah anda pernah membeli produk Tupperware?” apabila konsumen menjawab "ya" maka mereka dapat meneruskan mengisi kuesioner. Apabila jawabannya "tidak" maka sistem di kuesioner online tidak memberikan akses untuk melanjutkan pengisian.

Teknik sampel yang digunakan adalah non-probability sampling dengan purposive sampling, dimana sampel dipilih berdasarkan pertimbangan tertentu (Hair et al., 2010). Jumlah sampel yang digunakan berdasarkan Hair et al. (2010) adalah : N x 5-10 indikator, dimana $\mathrm{N}$ adalah jumlah pertanyaan. Dalam penelitian ini terdapat 40 pertanyaan yang valid, sehingga 40 x 5 (jumlah minimal) adalah 200 responden. 
Setelah jumlah minimal responden telah terkumpul, data diolah dengan menggunakan SPSS ver.20. Pengolahan data dilakukan melalui tahapan uji asumsi klasik untuk mengetahuan kenormalan data, tahapan berikutnya adalah statistik deskriptif untuk nilai ratarata setiap variabel dan standard deviasi. Data kemudian di tes dengan uji-T yaitu uji partial satu persatu variabel independen terhadap variabel dependen. Selain uji partial, data juga di uji secara simultan (uji-F). Tahapan akhir adalah uji koefisien determinasi untuk mengetahui kontribsui variabel independen terhadap dependen dan korelasi. (uji-R).

\section{HASIL PENELITIAN DAN PEMBAHASAN}

\section{Uji Validitas dan Reliabilitas}

Pegujian validitas dan reliabilitas dilakukan terhadap 30 responden dengan indikator $>$-tabel $=0,361(\mathrm{~N}=30$ pada $\alpha=5 \%)$. Dari 40 pertanyaan, semua pertanyaan memiliki angka diatas 0,361 yaitu berkisar 0,475 sampai 0,933. Maka semua pertanyaan valid (Hair et al., 2010). Demikian juga dengan pengujian reliabilitas per variabel, semua variabel menunjukkan reliabilitas yang sangat tinggi yaitu 0,809 sampai dengan 0,942 (Ghozali, 2016).

\section{Data Responden}

Responden dalam penelitian ini adalah 200 perempuan dan atau sebagai pembeli maupun agen penjualan. Berdasarkan tabel 1 dapat dilihat bahwa mayoritas responden adalah dealer / agen penjualan sebesar $78 \%$ dan sisanya konsumen sebesar 22\%. Berdasarkan Pendidikan, mayoritas berpendidikan SLTA atau sederajat sebanayak 50\%, kemudian Diploma- S1 sebesar $46 \%$ dan sisanya lain-lain sebesar $4 \%$ yang terdiri SMP dan 2 diantaranya berpendidikan S2. Data domisili menunjukkan ahwa mayoritas responden bertempat tinggal di DKI / Banten sebesar 38\%, Jawa Barat 24\%, Jawa Timur 21\% dan sisanya Jawa Tengah / DIY $17 \%$. 


\begin{tabular}{lcc}
\multicolumn{3}{c}{ Tabel 1. Profil Responden } \\
\hline \multicolumn{1}{c}{ Demografi } & Jumlah & Persentase \\
\hline Dealer: & & \\
Tidak & 44 & $22 \%$ \\
Ya & 156 & $78 \%$ \\
\hline Pendidikan : & & \\
SLTA & 101 & $50 \%$ \\
Diploma-S1 & 92 & $46 \%$ \\
Lainnya & 7 & $4 \%$ \\
\hline Domisili : & & \\
DKI / Banten & 76 & $38 \%$ \\
Jawa Barat & 47 & $24 \%$ \\
Jawa Tengah / DIY & 34 & $17 \%$ \\
Jawa Timur & 43 & $21 \%$ \\
\hline \multicolumn{1}{c}{$\quad$ S } &
\end{tabular}

Sumber : Kuesioner yang diolah, 2019

\section{Uji Asumsi Klasik}

Pengujian ini untuk mengetahui apakah data mengalami penyimpangan atau tidak, sehingga memiliki kelayakan untuk proses selanjutnya (Ghozali, 2016). Uji KorrmogorovSmirnov menunjukkan hasil 0,102 > 0,05, maka nilai residual terdistibusi normal. Uji P-P Plot menunjukkan nilai residual yang terdistribusi normal, dimana titik-titik menyebar dan mengikuti arah garis diagonal (Ghozali, 2016).

Demikian juga dengan uji Multiko-liniaritas, nilai yang dilihat adalah nilai Tolerance dan VIF. Nilai tersebut untuk mengetahui apakah terdapat korelasi antara variabel bebas atau tidak. Jika tidak terdapat korelasi, maka data memenuhi syarat untuk diolah pada tahap selanjutnya. Nilai Tolerance untuk semua variabel adalah $>0,10$ maka tidak terjadi multikolinieritas pada semua variabel. Jika dinilai dari nilai VIF semua variabel $<10,00$ sehingga tidak terjadi multikolinearitas (Ghozali, 2016).

Uji Scatterplot menunjukkan bahwa titik-titik menyebar tanpa pola tertentu dengan menyebar ke atas, bawah, kiri dan kanan. Kondisi ini menunjukkan bahwa data tersebut tidak terjadi heteroskedasitas (Ghozali, 2016).

\section{Deskriptif Statistik}

Hasil deskriptif statistik menunjukkan bahwa mean tertinggi terdapat pada variabel Brand Image sebesar 4,37 (Sangat Setuju), artinya reponden sangat setuju bahwa Brand Image Tupperware sangat baik. Sedangkan variabel lainnya yaitu Green Product, Green Price, Green Place dan Green Promotion berada di area Setuju (3,41 - 4,20) artinya responden ber-pendapat bahwa semua variabel independen memiliki produk, harga, lokasi dan promosi ramah lingkungan yang baik. 
Tabel 2. Deskriptif Statistik

\begin{tabular}{lcc}
\hline \multicolumn{1}{c}{ Variabel } & Mean & $\begin{array}{c}\text { Standard } \\
\text { Deviation }\end{array}$ \\
\hline Green Product & 4,03 & 5,37 \\
Green Price & 3,19 & 4,63 \\
Green Place & 3,56 & 5,21 \\
Green Promotion & 3,80 & 4,85 \\
Brand Image & 4,37 & 3,97 \\
\hline \multicolumn{2}{c}{ Sumber: Kuesioner yang diolah, 2019 }
\end{tabular}

\section{Analisis Linear Berganda}

Pada tabel 3 dapat disimpulkan bahwa secara partial terdapat pengaruh positif dan signifikan Green Product terhadap Brand Image karena $0.010<0.050$ (Ghozali, 2016). Demikian juga dengan Green Price berpengaruh positif dan signifikan terhadap Brand Image dengan nilai $0.000<0.500$. Hal yang sama juga ditunjukkan oleh Green Place yaitu berpengaruh positif dan signifikan terhadap Brand Image dengan nilai 0.009<0.050 (Ghozali, 2016). Sedangkan Green Promotion tidak berpengaruh terhadap Brand Image karena memiliki nilai $0.062>0.050$ (Ghozali, 2016). Putripeni et al. (2014) yang meneliti produk ramah lingkungan yaitu Bodyshop menyimpulkan hasil penelitian yang sama, dimana green product, green price dan green place berpengaruh terhadap citra merek, namun green promotion tidak berpengaruh. Hasil penelitian ini berbeda dengan penelitian terdahulu (Rahmat \& Silvianita, 2016) dimana variabel green product dan promotion berpengaruh terhadap brand image. Namun green price dan green place tidak berpengaruh.

Tabel 3. Hasil Uji Linear Berganda

\begin{tabular}{lrrrr}
\hline \multicolumn{1}{c}{ Model } & \multicolumn{2}{c}{$\begin{array}{c}\text { Unstandardized } \\
\text { Coefficients }\end{array}$} & t & Sig. \\
& B & Std.Error & & \\
\hline (Constant) & 15.975 & 1.949 & 8.198 & .000 \\
G. Produk & .129 & .050 & 2.606 & .010 \\
G.Price & .247 & .060 & 4.121 & .000 \\
G.Place & .137 & .052 & 2.650 & .009 \\
G.Promotion & .112 & .060 & 1.874 & .062 \\
\hline \multicolumn{5}{c}{ Sumber : Kuesioner yang diolah, 2019 }
\end{tabular}

Berdasarkan tabel 3, maka persamaan linear berganda dapat dijelaskan sebagai berikut :

$Y=15,975+0,129 X_{1}+\mathbf{0 , 2 4 7} X_{2}+0,137 X_{3}$ Berdasarkan rumus tersebut, variabel independent yang paling berpengaruh adalah Green Price yaitu sebesar 24,7\%. Sedangkan variabel Green Product hanya sebesar 12,9\% dan Green Place sebesar 13,7\%. Hasil penelitian ini berbeda dengan hasil penelitian Putripeni et al. (2014) yang menyimpulkan 
bahwa variabel yang paling berpengaruh terhadap brand image adalah produk. Penelitian penulis terdahulu (Genoveva \& Levina, 2019) pada topik terkait menyimpulkan bahwa green place adalah variabel yang paling berpenagruh. Perbedaan dapat terjadi karena perbedaan reponden dan jumlah responden, lokasi dan produk.

Tabel 4. Anova

\begin{tabular}{lcrrrr}
\hline Model & $\begin{array}{c}\text { Sum of } \\
\text { Squares }\end{array}$ & Df & $\begin{array}{c}\text { Mean } \\
\text { Square }\end{array}$ & F & Sig. \\
\hline Regression & 1043.454 & 4 & 260.864 & 24.276 & .000 \\
Residual & 2095.421 & 195 & 10.746 & & \\
Total & 3138.875 & 199 & & & \\
\hline \multicolumn{5}{c}{ Sumber : Kuesioner yang diolah, 2019 } \\
\hline \multicolumn{7}{c}{}
\end{tabular}

Dari hasil pengujian pada penelitian ini diperoleh nilai $\mathrm{F}$ hitung pada tabel diatas adalah 24,276. Dengan $\alpha=0,05$, nilai $\mathrm{k}=4$ dan $\mathrm{n}=200$ dapat memperoleh nilai $\mathrm{F}$ tabel $\mathrm{df}$ 2,42 yang artinya nilai $F_{\text {hitung }}>F_{\text {tabel }}$, dan dapat dilihat diatas bahwa nilai signifikansi sebesar $0,000<0,05$ yang dapat disimpulkan bahwa variabel independen berpengaruh signifikan terhadap variabel dependen yaitu Brand Image secara simultan, $\mathrm{H}_{0}$ ditolak dan $\mathrm{H}_{\mathrm{a}}$ diterima. Pada penelitian terdahulu, (Dhuha, Rofiaty, \& Sunaryo (2015) menggunakan SEM dalam pengolahan data terhadap 160 reponden Bodyshop, menunjukkan bahwa green marketing mix berpengaruh terhadap brand image yang merupakan bagian dari brand equity Bodyshop. Demikian juga dengan Simão \& Lisboa (2017), metode penelitian yang digunakan adalah kualitatif pada perusahaan Toyota yang menerapkan strategi green marketing. Strategi ini terbukti meningkatkan brand image sehingga menjadi produk nasional terkenal di Portugis. Aldoko, Suharyono, \& Yuliyanto (2016) juga menyimpulkan hal yang sama, yaitu green marketing mix mempengaruhi brand image produk Tupperware yang merupakan produk ramah lingkungan. Meskipun ketiga penelitian terdahulu menggunakan lokasi, waktu dan responden yang berbeda dan dua diantara menggunakan produk yang berbeda, serta pengolahan data yang berbeda dengan penulis, hasil penelitian menunjukkan bahwa green marketing mix mempengaruhi brand image.

\section{Koefisien Determinasi}

Tabel 5 menunjukkan bahwa kontribusi independen variabel terhadap dependen sebesar $31,9 \%$, sisanya $68,1 \%$ dipengaruhi oleh faktor lain yang tidak teliti dalam penelitian ini. Pada penelitian Aldoko et al. (2016) menunjukkan bahwa kontribusi variabel green marketing mix terhadap brand image sebesar 45,8\% artinya faktor lain yang tidak diteliti lebih besar kontribusinya dibandingkan green marketing mix, hasil ini menunjukkan 
kesimpulan yang senada dengan penulis yaitu faktor diluar green marketing mix lebih berpengaruh.

Nilai R pada tabel 5 menunjukkan korelasi variabel independen terhadap dependen cukup kuat karena 0,577 > 0,050 (Ghozali, 2016).

Tabel 5. Model Summary

\begin{tabular}{ccccc}
\hline Model & $\mathbf{R}$ & $\begin{array}{c}\mathbf{R} \\
\text { Square }\end{array}$ & $\begin{array}{c}\text { Adjusted } \\
\mathbf{R} \\
\text { Square }\end{array}$ & $\begin{array}{c}\text { Std.Error } \\
\text { of the } \\
\text { Estimate }\end{array}$ \\
\hline 1 & .577 & .322 & .319 & 3.278 \\
\hline \multicolumn{4}{c}{ Sumber $:$} & Kuesioner \\
yang diolah, & 2019
\end{tabular}

\section{KESIMPULAN DAN SARAN}

Secara partial Green Product, Green Price dan Green Place berpengaruh posi-tif dan signifikan terhadap Brand Image Tupperware. Sedangkan Green Promotion tidak berpengaruh terhadap Brand Image Tupperware.

Secara simultan variabel independent (Green Product, Green Price, Green Place dan Green Promotion) berpengaruh positif dan signifikan terhadap Brand Image Tupperware. Green Price memberikan kontibusi terbesar terhadap Brand Image Tupperware, berdasarkan kesimpulan ini perusahaan Tupperware diharapkan dapat memperhatikan faktor harga, dimana harga yang ditawarkan harus sesuai dengan produk yang didapatkan dan memberikan nilai tambah bagi lingkungan, sehingga konsumen (khususnya kaum wanita yang merupakan $100 \%$ dari responden dan sekaligus sebagai tim pemasaran) yang memiliki perhatian terhadap lingkungan dapat ikut mendukung pembelian produk Tupperware dengan persepsi bahwa dengan membeli dan memakai produk Tupperware konsumen turut menjaga kelestarian lingkungan. Pada dasarya konsumen bersedia membayar apabila sesuai dengan brand image produk.

Tim jaringan pemasaran yang terdiri dari kaum wanita dapat di edukasi mengenai keberlangsungan lingkungan dengan menggunakan produk yang dapat dipakai berulang seperti Tupperware. Tupperware setelah melakukan re-brand juga memperkenalkan produk yang dapat dipakai di microwave dengan tampilan kekinian, sehingga pilihan untuk melestarikan lingkungan lewat pembelian Tupperware semakin terbuka lebar.

Untuk peneliti yang akan datang, karena kontribusi seluruh variabel independent (Green Product, Green Price, Green Place dan Green Promotion) hanya 31,9\% dan sisanya $68,1 \%$ dipengaruh faktor lain, peneliti dapat mencari variabel independen lain seperti gaya hidup (life style), motivasi, kepercayaan (trust) dan penjualan online sebagai variabel 
Genoveva \& Berliana. (2021). Pengaruh Green Marketing Mix terhadap ...

independent sebagai alternatif penelitian. Penambahan jumlah responden akan memberikan hasil yang lebih maksimal karena dapat mewakili lebih banyak konsumen. 


\section{DAFTAR PUSTAKA}

Aaker, D. A. (2014). Aaker on Branding: 20 Principles that drive Success. Morgan James Publishing.

Agustin, R. D., Kumadji, S., \& Yulianto, E. (2015). Pengaruh Green Marketing Terhadap Minat Beli Serta Dampaknya Pada Keputusan Pembelian. Jurnal Administrasi Bisnis, 22(2), 1-10.

Aldoko, D., Suharyono, S., \& Yuliyanto, E. (2016). PENGARUH GREEN MARKETING TERHADAP CITRA MEREK DAN DAMPAKNYA PADA KEPUTUSAN PEMBELIAN (Survei pada Mahasiswa Fakultas Ilmu Administrasi 2012/2013 Universitas Brawijaya yang Melakukan Pembelian Produk Tupperware). Jurnal Administrasi Bisnis S1 Universitas Brawijaya.

Antika, N. (2017). 50\% Penjualan Tupperware Ada di Pulau Jawa. Retrieved from industri.kontan.co.id: https://industri.kontan.co.id/news/50-penjualan-tupperware-adadi-pulau-jawa

Ayu, C. P., \& Wardhana, A. (2016). Pengaruh Green Marketing Mix terhadap Brand Image The Bodyshop Pada Store Festival Citilink Bandung. In e-Proceeding of Management (pp. 446-453).

Choirun, A. (2018). Indonesia Darurat Sampah. Retrieved from https://www.kompasiana.com/achnes/5b86ab3643322f3c060ed01c/indonesia-daruratsampah

Dhuha, R. Y., Rofiaty, \& Sunaryo. (2015). The Effect of Green Marketing, Corporate Social Responsibility on Brand Equity and Customer Loyalty. European Journal of Business and Management, 7(34), 93-103.

Dwipamurti, I. G. A. N., Mawardi, M. K., \& Nuralam, I. P. (2018). The Effect of Green Marketing on Brand Image and Purchase Decision (Study on Consumer of Starbucks Café Ubud, Gianyar Bali). Jurnal Administrasi Bisnis (JAB), 61(3), 57-64.

FuiYeng, W., \& Yazdanifard, R. (2015). Green Marketing: A Study of Cosumer Buying Behavior in Relation to Green Products. Global Journal of Management and Business Research, 15(5), 1-8.

Genoveva, G. (2016). Factor Affecting Consumers' Green Purchase Bhavior (An Empirical Study of Indonesia Pay Plastic Policy). International Journal of Business, Economics and Law, 10(2), 31-36. 
Genoveva, G., \& Levina, L. (2019). The Green Marketing Mix: A Review of Customers' Bodyshop Purchase Intention. Jurnal Muara Ilmu Ekonomi Dan Bisnis, 3(2), 400-409. https://doi.org/10.24912/jmieb.v3i2.7386

Genoveva, G., \& Samukti, D. R. (2020). Green Marketing: Strengthen The Brand Image and Increase The Customer's Purchase Decision. MIX: Jurnal Ilmiah Manajemen, 367-384. https://doi.org/10.22441/mix.2020.v10i3.004

Ghozali, I. (2016). Aplikasi Analisis Multivariate dengan Program IBM SPSS 23 (8th ed.). Semarang: Badan Penerbit Universitas Diponegoro.

Hair, J. F., Anderson, R. E., Tatham, R. L. and, \& Black, W. C. (2010). Multivariate Data Analysis: A Global Perspective (7th ed.). New Jersey: Pearson Prentice Hall.

Hasan, Z., \& Ali, N. A. (2015). The Impact of Green Marketing Strategy on the Firm's Performance in Malaysia. Procedia - Social and Behavioral Sciences, 172, 463-470. https://doi.org/10.1016/j.sbspro.2015.01.382

Index, T. B. (2017). Top Brand Award. Retrieved from http://www.topbrand-award.com/topbrand-Survey/surveyresult/top_brand_index_2017

Kalsi, P. S., \& Singh, I. (2015). Impact of Green Marketing Mix on Consumers' Purchase Behaviour: A Study in the Jalandhar Region of Punjab. International Journal of Engineering and Management Research, 5(1), 267-272.

Karunarathna, A. K. P., Bandara, V. K., Silva, A. S. T., \& De Mel, W. D. H. (2020). Impact of Green Marketing Mix on Customers' Green Purchasing Intention with Special Reference to Sri Lankan Supermarkets. South Asian Journal of Marketing, 1(1), 127153.

Keller, K. . K. (2010). Strategic Brand Management: Building, Measuring, and Managing Brand (4th ed.). New York: Pearson Education.

Kotler, P., \& Keller, K. L. (2017). Marketing Management. Global Edition: Pearson Education.

Kumar, P., \& Ghodeswar, B. M. (2015). Factors Affecting Consumers' Green Product Purchase Decisions. Marketing Intelligence and Planning, 33(3), 330-347. https://doi.org/10.1108/MIP-03-2014-0068

Mahmoud, T. O. (2018). Impact of Green Marketing Mix on Purchase Intention. International JOurnal of Advanced and Applied Science, 5(2), 127-135. https://doi.org/10.21833/ijaas.2018.02.020

Mahmoud, T. O., Ibrahim, S. B., Ali, A. H., \& Bleady, A. (2017). The Influence of Green 
Marketing Mix on Purchase Intention: The Mediation Role of Environmental Knowledge. International Journal of Scientific \& Engineering Research, 1040-1048. https://doi.org/10.14299/ijser.2017.09.006

Masterson, R., \& Pickton, D. (2014). Marketing: An Introduction Paperback. New Delhi: SAGE Publication.

Mothersbaugh, D. L., \& Hawkins, D. I. (2015). Consumer Behavior: Building Marketing Strategy (13th ed.). New York: Mc Graw Hill Education.

News, D. S. (2019). Tupperware Q4 2018 Net Sales Down. Retrieved from https://www.directsellingnews.com/tupperware-q4- 2018-net-sales-down-14/

Nguyen, N. T. H., \& Nguyen, D. T. N. (2018). Impact of Green Marketing on Green Brand Image and Equity in Banking Sector. WSEAS Transaction on Business and Economics, $15,452-460$.

Olivar, M. (2018). Rethinking Plastic Globally. Retrieved November 6, 2018, from https://www.sustainalytics.com/esg-blog/rethinking-plastic-globally/

Putripeni, M. P., Suharyono, \& Kusumawati, A. (2014). Pengaruh Green Marketing Terhadap Citra Merek Dan Keputusan Pembelian (Studi Pada Konsumen The Bodyshop Mall Olympic Garden Malang). Jurnal Administrasi Bisnis, 10(1), 1-10.

Rahmat, R. M., \& Silvianita, A. (2016). Pengaruh Green Marketing Terhadap Bodyshop pada Strore Trans Studio Mall Bandung. E-Proceeding of Management, 3(2), 1903-1910.

Rajeshkumar, L. (2012). An Overview of Green Marketing. Naamex International Journal of Management Research, 2(1), 128-135.

Re-brand. (2018). Re-brand 100: Distinction. Retrieved from https://rebrand.com/distinctiontupperware/

Romadon, Y., Kumadji, S., \& Abdillah, Y. (2014). Pengaruh Green Marketing Terhadap Brand Image dan Struktur Keputusan Pembelian (Survei pada Followers Account Twitter@PertamaxIND Pengguna Bahan Bakar Ramah lingkungan Pertamax Series). Jurnal Administrasi Bisnis, 15(1).

Sari, I., \& Setiawan, P. (2017). Pengaruh Green Marketing dan Packaging Terhadap Brand Image dan Loyalitas Pelanggan Pada Konsumen Starbucks Coffee. E-Jurnal Manajemen Universitas Udayana, 6(7), 3820-3849.

Sharma, M., \& Trivedi, P. (2016). Various Green Marketing Variables and Their Effects on Consumers' Buying Behaviour for Green Products. IJLTEMAS, 5(1), 1-8. 
Silvia, F. (2014). Pengaruh Green Marketing Terhadap Citra Merek Serta Dampaknya Pada Keputusan Pembelian (Survei pada Konsultan Independen di Oriflame Cabang Surabaya). Jurnal Administrasi Bisnis, 20(10), 1-10.

Simão, L., \& Lisboa, A. (2017). Green Marketing and Green Brand - The Toyota Case. Procedia Manufacturing, 12, 183-194. https://doi.org/10.1016/j.promfg.2017.08.023

Solaiman, M., Osman, A., Suberi, M., \& Halim, B. A. (2015). Green Marketing: A Marketing Mix Point of View. International Journal of Business and Technopreneurship, 5(1), 8798.

Sugiyono. (2017). Metode Peneiltian Kuantitatif, Kualitatif dan R\&D. Bandung: CV Alfabeta.

Supriadi, C. (2015). Tupperware Galakan Kampanye Lingkungan TGI. Retrieved from https://marketing.co.id/ tupperware-galakan-kampanye-lingkungan-tgif/ 